\title{
ОСОБЛИВОСТІ ВОГНЕВОЇ ПІДГОТОВКИ ПОЛІЦЕЙСЬКИХ НА ПОЧАТКОВОМУ ЕТАПІ НАВЧАННЯ
}

Головацький О. О., Прядко В. М.

у науковій роботі розглядається методика вдосконалення поліцейськими навичок володіння вогнепальною зброєю. Акцентовано увагу на переході від початкового етапу вогневої підготовки до етапу вдосконалення набутих навичок стрільби поліцейськими, які проходять навчання вогневої підготовки.

Визначено ознаки, які характеризують придбані необхідні навички стрілка і його готовність до вищезазначе ного переходу. Запропоновано і обгрунтовано рекомендації стрілку й інструктору, які передбачають виконання пострілу по схемі «рух - постріл - рух».

Ключові слова: поліцейський, вогнева підготовка, вогнепальна зброя, постріл, табельна зброя, формування навичок, методика навчання, стрілок, службова підготовка, психологічна готовність.

В научной работе рассматривается методика совершенствования полицейскими навыков владения огнестрельным оружием. Акцентировано внимание на переходе от начального этапа огневой подготовки до этапа совершенствования приобретенных навыков стрельбы полицейскими, которые проходят обучение огневой подготовке.

Определены признаки, которые характеризуют приобретенные необходимые навыки стрелка и его готовность к вышеуказанному переходу. Предложены и обоснованы рекомендации стрелку и инструктору, предполагающие выполнение выстрела по схеме «движение - выстрел - движение».

Ключевые слова: полицейский, огневая подготовка, огнестрельное оружие, выстрел, табельное оружие, фор мирование навыка, методика обучения, стрелок, служебная подготовка, психологическая готовность.

This research article reveals methodology for improving policemen' skills at firearms. Attention is focused on the transition from the initial stage of firearm training to the stage of improving the acquired skills of shooting by police officers.

The existing methods of training for various types of firearms shooting, which have an initial stage and a stage of improvement of skills, are analyzed. It is substantiated that the transition from one stage to the next is possible only when police officers who are trained in firing firearms have made significant progress in mastering the elements of the preparation of the previous stage.

The mechanism of formation of the skill of bringing to the automatism of the mechanisms of switching modes of operation of the motor system of the arrow, which allows a positive result to be achieved, when the shooter for a certain period of time worked out an exercise with a firearm in motion, breaking it into separate components, which in the future gives him the opportunity to professionally execute the shot in motion.

The features characterizing the acquired necessary skills of the shooter and his readiness to abovementioned transition are defined: the correct awareness of their own mistakes, the ability to analyze their own shooting and the actions of other shooters; ability to manage their actions in terms of time limit; ability to control the shooting technique in competitive conditions; quick adaptability to the shooting of "alien" weapons. It is concluded

Головацький О. О., Прядко В. М., 2019 that these signs indicate the manifestation of the main qualities of the shooter, which ensure the success of shooting: reliability, stability, mobility, and also contribute to the formation of movement skills, worked out to automatism.

Recommendations to the shooting instructor and shooters, suggesting taking a shot according to the scheme "movement shot - movement", are proposed and justified.

Key words: policeman, firearm training, firearm, shot, department-issued sidearm, skill formation methodic of education, shooter, service training, mental set.

Постановка проблеми та їі актуальність. Останнім часом спостерігається значне зростання кількості злочинів, пов'язаних із використанням вогнепальної зброї. При цьому в багатьох випадках зброя використовується проти працівників Національної поліції України, які повинні володіти відповідною професійною підготовкою щодо застосування вогнепальної зброї з метою протистояння озброєним злочинцям. До вказаного слід додати ще один фактор, який підтверджує підвищення уваги до високоякісної вогневої підготовки органів та підрозділів Національної поліції України під час виконання ними своїх функціональних обов'язків. Цим фактором $\epsilon$ неконтрольоване поширення зброї серед населення, у тому числі у середовищі злочинців. Вважаємо, що такому негативному явищу сприяло і погіршення суспільно-політичної та економічної ситуації в Україні, і криміналізація суспільства. У результаті незаконно отримана зброя, що збувається злочинцями, критично впливає на загальну криміногенну ситуацію, а застосування зброї створює реальну загрозу громадській безпеці і громадському порядку в цілому в країні. Водночас більшість тяжких злочинів, зокрема й терористичної спрямованості, учиняються саме з використанням зброї, боєприпасів, вибухових речовин і вибухових пристроїв.

У контексті викладеного наразі маємо офіційні статистичні дані щодо кількості правопорушень із застосуванням вогнепальної зброї та вибухівки, яка протягом року збільшилася майже в три рази [1]. Ми погоджуємося із думкою експертів, які вважають, що причиною цього $\epsilon$ недосконалий контроль за переміщенням зброї на території України [2, с. 66]. У свою чергу, Служба безпеки України неодноразово застерігала, що небезпека потрапляння вогнепальної зброї та засобів ураження у некерований обіг сприяє використанню його з терористичною або екстремістською метою та може спричинити жертви серед мирного населення [3]. На жаль, на даний момент часу в різних регіонах України такі випадки $є$ непоодинокими. Відповідно до викладеного постає необхідність у підвищенні рівня вогневої підготовки поліцейських вже на початковому етапі їх навчання.

Метою статті $\epsilon$ визначення особливостей вогневої підготовки поліцейських на початковому етапі навчання, а також розроблення конкретних пропозицій і реко- 
мендацій щодо підвищення рівня вогневої підготовки поліцейських в Україні шляхом виконання тренувальних вправ.

Аналіз останніх досліджень і публікацій. Окремі аспекти підвищення рівня вогневої підготовки поліцейських досліджувалися у працях М.І. Ануфрієва, С.М. Банаха, В.Р. Булачека, Г.Н. Будаг'янц, І.С. Винярчука, Ю.Р. Йосипіва, Ю.А. Лапутіної, М.А. Чміля та інших авторів.

Виклад основного матеріалу. Варто зазначити, що табельна зброя в руках професіонала $\epsilon$ не тільки символом влади, але й дієвим засобом у боротьбі з кримінальними структурами, тому навчання стрільбі зокрема з пістолета виступає важливим елементом в системі професійної підготовки поліцейських вже на перших етапах їх навчання. Вважаємо, що у даному випадку слід акцентувати увагу на двох варіантах застосування табельної зброї у службовій діяльності: під час стрільби на відстані до 25 м, що вимагає хороших професійних навичок, знання тактико-технічних характеристик табельної зброї, і під час стрільби в умовах безпосередньої близькості до злочинця на відстані 3-10 м, де необхідні швидка реакція, володіння філігранною технікою швидкісної стрільби і тактичними прийомами відходу з лінії вогню [4, с. 215].

Враховуючи те, що вогнева підготовка $\epsilon$ одним з основних предметів професійної службової підготовки поліцейських, відповідно вона спрямована на формування стійких навичок у поводженні з вогнепальною зброєю, навчання поліцейських діяти в умовах, пов'язаних із ефективним і правомірним його застосуванням. Професійне володіння поліцейськими вогнепальною зброєю у подальшому дозволить їм не тільки професійно виконувати свої обов'язки, але й в екстремальних випадках зберегти своє життя та життя інших людей від протиправних посягань злочинців.

У контексті досліджуваного питання варто зазначити, що нормативне забезпечення досліджуваного питання передбачене наказом МВС України № 50 від 26 січня 2016 року «Про затвердження Положення про організацію службової підготовки працівників Національної поліції України», в якому визначено порядок планування, проведення та обліку занять, здійснення контролю знань, умінь та навичок осіб молодшого, середнього та вищого складу Національної поліції України. Відповідно до п. 6 зазначеного підзаконного нормативно-правового акту різновидами службової підготовки, серед іншого, є вогнева підготовка. Нагадаємо, що вогнева підготовка передбачає комплекс заходів, спрямованих на вивчення поліцейським основ стрільби з вогнепальної зброї, правомірного іï застосування (використання) та вдосконалення навичок безпечного поводження з нею, швидкісної та влучної стрільби по нерухомих і рухомих цілях, з різних положень, в обмежений час, в русі тощо [5]. Як неодноразово нами було відмічено, що рівень володіння вогнепальною зброєю поліцейськими, їх знання нормативної бази щодо застосування цієї зброї, створює основи для особистої безпеки і дотримання громадського порядку в нашій країні.

Наявні методики навчання різним видам стрільби з вогнепальної зброї мають початковий етап і етап вдосконалення навичок. Перехід від одного етапу до наступного можливий лише в тому випадку, коли у поліцейських, які навчаються стрільбі з вогнепальної зброї, з'явився значний прогрес в освоєнні елементів підготовки попереднього.

Відмінною особливістю початкового етапу $\epsilon$ те, що при виконанні підготовчих вправ у поліцейських формуються базові навички у відпрацюванні елементів здійснення пострілу. У той же час частина стрільців потребує подолання психологічного бар'єру, що впливає на правильність їх дій (очікування пострілу, почуття страху перед бойовою зброєю, звук пострілу, віддача зброї після пострілу). При цьому важливим моментом $\epsilon$ те, що поки той, якого навчають володінню та застосуванню вогнепальної зброї, не досягне стійкого позитивного результату під час виконання підготовчих вправ, який не знайде упевненості в собі і в правильності своїх дій зі зброєю, перехід до наступного етапу не дасть позитивних результатів, ба більше - може призвести до закріплення помилок, що допускаються стрільцем на початковому етапі.

У сучасній практиці сформовано ряд ознак, які свідчать про те, що навички стрілка сформувалися достатньою мірою, і це дає можливість переходити до етапу вдосконалення навичок. Зокрема, до них належать такі: правильне усвідомлення власних помилок, уміння аналізувати свою стрільбу і дії інших стрільців; уміння управляти своїми діями в умовах ліміту часу; здатність керувати своєю стрільбою у змагальних умовах; швидка пристосованість до стрільби з «чужої» зброї. Всі вищевказані ознаки свідчать про прояв у стрільця основних якостей, які забезпечують успішність стрільби: надійність, стабільність, рухливість, про формування навичок руху, відпрацьованих до автоматизму. Відзначимо, що на даному етапі стає можливою поступова зміна методики навчання і включення до неї нових, більш складних елементів.

Практика діяльності поліцейських показує, що в більшості випадків застосування зброї під час виконання поставлених перед ними завдань, здійснюється безпосередньо в русі або відразу після певних переміщень тіла стрілка (біг, стрибки, перекати, падіння). Відповідно до раніше закріплених навичок чітких і точних дій стрілка, яким є сам постріл, приєднуються більш прості по виконанню, проте значні за кількістю і амплітуді рухи тіла. Вся складність завдання полягає в тому, що рухова система стрілка повинна миттєво перебудуватися з одного режиму роботи на інший і забезпечити успішне досягнення мети. Це висуває особливі вимоги щодо змін у рухах поліцейського, який застосовує вогнепальну зброю.

У зв'язку з цим важливим є формування і подальше доведення до автоматизму механізмів перемикання режимів роботи рухової системи стрілка. У цьому разі можна досягти позитивного результату, коли стрілець протягом часу відпрацював вправу із вогнепальною зброєю у русі, розбиваючи іiі на окремі складові, що у подальшому надасть йому можливість професіонально виконати постріл у русі.

Вважаємо за необхідне розглянути у чому саме полягає механізм формування такого навику. Ученими доведено, що в процесі освоєння такого навику перш за все відбувається відкладення в свідомості образів елементів складних рухів. При достатньому рівні відпрацювання рухів вважається, що сформовані образи знаходяться у підсвідомості людини і відображені в ньому як окремими компонентами, так і у вигляді цілісної дії 
[6, с. 334]. У цей час якраз і відбувається доведення до автоматизму рухових навичок.

Вважаємо за необхідне рекомендувати інструкторам та поліцейським на початковому етапі навчання за для успішного досягнення вищезазначеної мети наступне.

Для поліцейських, які проходять навчання з вогневої підготовки, доречним є виконання таких рекомендацій. По-перше, стрілку не варто поспішати при відпрацюванні пострілу під час руху або безпосередньо одразу після переміщення. У цьому разі поліцейський, який навчається стрільби з вогнепальної зброї, повинен уважно стежити за інструктором і намагатися самостійно визначити, з яких елементів складається зазначена дія, а також які із них $\epsilon$ вирішальними для її успішного виконання. Бажано було б поліцейському уявити, як він самостійно виконуватиме поетапне переміщення.

По-друге, поліцейським, які проходять навчання з вогневої підготовки на перших заняттях після ознайомлення із різними вправами зі стрільби не треба прагнути виконувати їх за мінімальний час. Це може призвести до закріплення помилкових способів виконання, оскільки, виконуючи дуже швидко вправу і не маючи при цьому достатнього рівня вмінь та досвіду, стрілець компенсує дефіцит майстерності завдяки якості виконання [7, с. 10]. Як висновок, якщо навіть поліцейський і буде швидко стріляти, то в бойовій ситуації такий спосіб не забезпечить належного ступеня надійності і високої результативності.

По-третє, під час виконання вправи поліцейському не потрібно очікувати повного закінчення переміщення, натомість починати постріл необхідно в процесі руху, так, щоб в момент зупинки тіла залишилося тільки завершити вижимання спускового механізму. При цьому повної зупинки взагалі не повинно бути, оскільки на відміну від стрільби із стандартного статичного положення, виконання стрільби у русі не припиняється завершенням відпрацювання спуску. У цьому разі дію можна вважати закінченою лише тоді, коли стрілець повністю виконає переміщення після пострілу. Схематично це можна відобразити як «рух - постріл - рух». Деякі науковці пояснюють це прикладними особливостями даного виду стрільби, так як будь-який нерухомий, хоч на мить об'єкт $\epsilon$ зручною мішенню для ураження. Тому під час тренувань дуже важливо до автоматизму відпрацювати різні варіанти відходу від можливого зустрічного вогню [7, с. 13-14].

3 приводу рекомендацій для інструкторів варто зазначити, що не слід навчати поліцейських відразу декільком видам складних стрілецьких вправ. Поступове навчання певній складній стрілецькій вправі надасть можливість поліцейським, які навчаються вогневій підготовці, усвідомити ключові моменти щодо виконання вправ у русі.

Вважаємо, що інструкторам обов'язково слід звертати увагу на динаміку виконання поліцейськими складних вправ із переміщенням, а також із урахуванням інтервалів, необхідних для виконання як окремих елементів, так і цілісної дії.

Водночас важливим моментом $є$ постійне доповнення процесу навчання новим видам складних стрі- лецьких вправ прикладами з практики дій досвідчених поліцейських-професіоналів, із обов'язковим поясненням, які моменти привели до успіху, що призвело до невдачі, постійно вказувати на значущість тренування, сприяючи формуванню у стрільців упевненості в собі $[7$, с. 15].

Висновки. Отже, запропоновані та узагальнені рекомендації у даній науковій роботі не $є$ вичерпними. За наявності навчальної програми, тематичних планів та індивідуальних особливостей поліцейських, які навчаються вогневій підготовці, зазначені рекомендації можуть бути змінені. Вдночас поліцейський повинен бути психологічно готовий застосувати вогнепальну зброю по відношенню до злочинця, а також він повинен бути впевненим у правомірності застосування вогнепальної зброї у такій ситуації. Відповідно до викладеного, з метою формування у поліцейських професійних навичок застосування вогнепальної зброї незалежно від екстремальних ситуацій різного характеру, необхідно постійно приділяти увагу та підвищувати рівень вогневої підготовки в органах та підрозділах Національної поліції України.

\section{Література}

1. MBC: в Україні зростає незаконний обіг зброї. URL: http: / /www.dw.com/uk/мвc-в-україні-зростає-незаконний-обіг-зброї/а.

2. Мельник В.І. Незаконне розповсюдження й обіг зброї як загроза громадському порядку в сільській місцевості. Науковий вісник Херсонського державного універcumemy. 2016. Вип. 2. Т. 2. С. 66-70.

3. СБУ: незаконний обіг зброї - потенційна загроза. URL: http://www.prav-org.sm.gov.ua/index.php/uk/33upravlinnya-sluzhbi-bezpeki-ukrajini.

4. Чмиль М.А. Особенности психологической подготовки работников ОВД к стрельбе в экстремальных условиях. Право і безпека. 2004. Т. 3. № 2. С. 215-218.

5. Про затвердження Положення про організацію службової підготовки працівників Національної поліції України : Наказ Міністерства внутрішніх справ України № 50 від 26 січня 2016 р. URL: http://zakon3.rada.gov.ua/ laws/show/z0260-16\#n17.

6. Солодков А.С., Сологуб Е.Б. Физиология человека. Общая. Спортивная. Возрастная : учебник. 8-е изд. Москва : Спорт, 2018. 620 с.

7. Лапутина Ю.А. Огневая подготовка сотрудников спецподразделений по борьбе с терроризмом: метод. пособие. Киев, 1997. 37 с.

Головацький О. О., підполковник поліції, викладач кафедри тактико-спечіальної та вогневої підготовки

Одеського державного університету внутрішніх справ

Прядко В. М., майор поліції, старший викладач кафедри тактико-спеціальної та вогневої підготовки

одеського державного університету внутрішніх справ 